\title{
Yersinia enterocolitica infection with septic pulmonary embolism and liver and intestinal lymph node abscesses
}

\author{
Akihiro Dejima () , Naoki Yamamoto 다 , Kenkou Hasatani
}

Department of Internal Medicine, Suzu City General Hospital, Suzu, Ishikawa, Japan

Correspondence to Dr Akihiro Dejima; m06067an@jichi.ac.jp

Accepted 22 March 2021

\section{DESCRIPTION}

A 55-year-old man visited the hospital because of fatigue, fever and diarrhoea. He had no medical history and no medication. Physical examination revealed tenderness limited to McBurney's point without muscular defence or rebound tenderness, and coarse crackles were heard on the right lung field. Laboratory findings were as follows: white cell count: 17700 cells $/ \mathrm{mm}^{3}$; C reactive protein: $33.13 \mathrm{mg} / \mathrm{dL}$; aspartate aminotransferase: 37IU/L; alanine aminotransferase: 41IU/L; alkaline phosphatase: $935 \mathrm{IU} / \mathrm{L} ; \gamma$-glutamyl transpeptidase: $153 \mathrm{IU} / \mathrm{L}$; blood sugar level: $413 \mathrm{mg} /$ $\mathrm{dL}$; haemoglobin A1c level: 14.7\%; and D-dimer: $7.2 \mu \mathrm{g} / \mathrm{dL}$. PCR test for COVID-19 was negative. Contrast-enhanced CT (CECT) showed enhanced terminal ileum wall thickening, fluid collection, multiple bilateral pulmonary nodules, right pulmonary arterial thrombus and liver abscess (figure 1A-D). Antibiotic therapy with meropenem and intensive insulin therapy for diabetes were administered. Blood culture yielded Yersinia enterocolitica. According to blood culture results, the antibiotic drug was changed from meropenem to levofloxacin. The fever subsided on day 10 , and he was discharged home on day 28. CECT on day 36 showed that the enhanced terminal ileum wall thickening, fluid collection, multiple bilateral pulmonary nodules, right pulmonary arterial thrombus and liver abscess disappeared (figure 2A-D). $\mathrm{He}$ completed the antibiotic therapy and had no apparent comorbidities at 7 months of follow-up. Y. enterocolitica is a Gram-negative bacillus that may cause acute gastroenteritis infections, including sepsis and liver
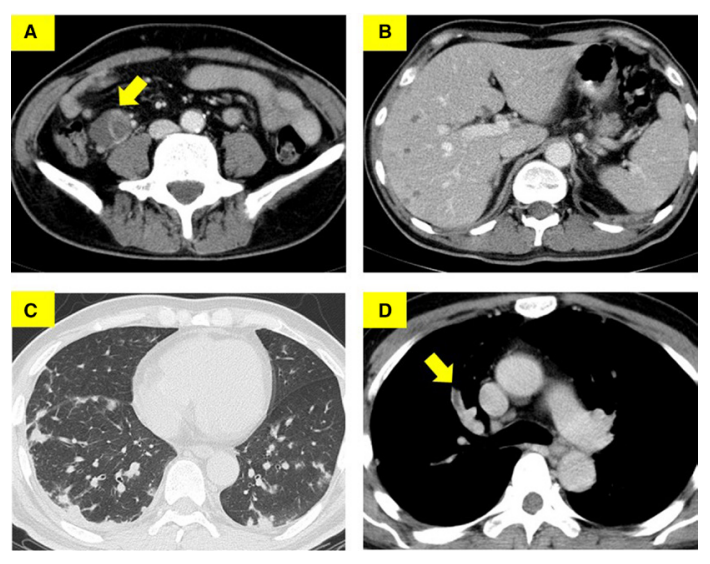

Figure 1 (A) Enhanced terminal ileum and fluid collection. (B) Liver abscess. (C) Multiple bilateral pulmonary nodules. (D) Thrombus of the right pulmonary artery.
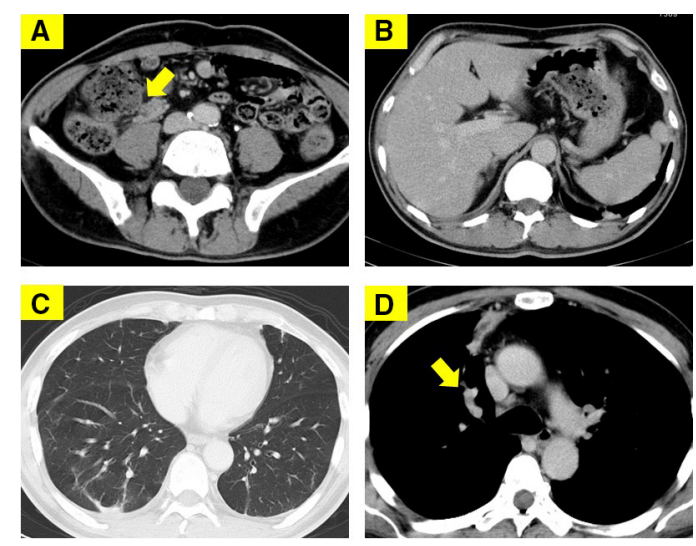

Figure 2 (A) Enhanced terminal ileum and fluid collection disappeared. (B) Liver abscess disappeared. (C) Multiple bilateral pulmonary nodules disappeared. (D) Thrombus of the right pulmonary artery disappeared.

abscesses. ${ }^{12}$ Enterocolitis is the most frequent presentation in young children, whereas acute mesenteric lymphadenitis and terminal ileitis are more likely to occur in older children and adults. Septicaemia mostly likely occurs in the elderly and compromised hosts. ${ }^{3}$ There are reports of septic pulmonary embolism (PE) caused by Y. pseudotuberculosis, but cases of septic PE caused by Y. enterocolitica have not been reported in PubMed. ${ }^{4}$ We report a rare case of Y. enterocolitica infection with septic PE. Septic PE is an uncommon disorder with an insidious onset and is difficult to diagnose. ${ }^{5}$ In septic PE, the embolic blood clot that leads to an infarction in the pulmonary vasculature also contains micro-organisms that incite a focal abscess. ${ }^{6}$ Since Yersinia species grow at temperatures lower than the normal culture temperatures, it is necessary to inform clinicians that they have identified Yersinia infections when submitting culture tests to the bacterial laboratory in advance. ${ }^{7}$ In immunocompromised patients, such as those with uncontrolled diabetes, infections caused by Y. enterocolitica should be considered, because it may be complicated by terminal ileitis and multiorgan abscess, as in this case.

\section{Learning points}

- Yersinia enterocolitica infection causes septic pulmonary embolism.

- Y. enterocolitica should be considered in immunocompromised adults with terminal ileitis and multiorgan abscess. 
Images in...

Acknowledgements We would like to thank Editage (www.editage.com) for English language editing.

Contributors $A D$ and $K H$ contributed to planning. $A D$ and $N Y$ contributed to conduct. All authors contributed to the concept and design of the work. AD and NY contributed to data collection. All authors contributed to data analysis and interpretation. AD and NY contributed to drafting the article. All authors contributed to critical revision of the article.

Funding The authors have not declared a specific grant for this research from any funding agency in the public, commercial or not-for-profit sectors.

Competing interests None declared.

Patient consent for publication Obtained.

Provenance and peer review Not commissioned; externally peer reviewed.

\section{ORCID iDs}

Akihiro Dejima http://orcid.org/0000-0002-8422-2406
Naoki Yamamoto http://orcid.org/0000-0002-4113-0499

\section{REFERENCES}

1 Minami K, Yasuda R, Terakawa R, et al. Four sporadic pediatric cases of Yersinia enterocolitica 0:8 infection in a rural area of Japan. Jpn J Infect Dis 2017;70:192-4.

2 Bottone EJ. Yersinia enterocolitica: a panoramic view of a charismatic microorganism. CRC Crit Rev Microbiol 1977;5:211-41.

3 Portnoy D, Martinez LA. Yersinia enterocolitica septicemia with pneumonia. Can Med Assoc J 1979;120:61-2.

4 Takahashi Y, Sasabe J, Maeda H, et al. [First case of lung abscess due to Yersinia pseudotuberculosis in Japan]. Kansenshogaku Zasshi 2014;88:463-8.

5 King MB, Harmon KR. Unusual forms of pulmonary embolism. Clin Chest Med 1994;15:561-80.

6 Cook RJ, Ashton RW, Aughenbaugh GL, et al. Septic pulmonary embolism: presenting features and clinical course of 14 patients. Chest 2005:128:162-6.

7 Hanna MO, Zink DL, Carpenter ZL, et al. Yersinia enterocolitica-like organisms from vacuum-packaged beef and lamb. J Food Sci 1976;41:1254-6.

Copyright 2021 BMJ Publishing Group. All rights reserved. For permission to reuse any of this content visit

https://www.bmj.com/company/products-services/rights-and-licensing/permissions/

BMJ Case Report Fellows may re-use this article for personal use and teaching without any further permission.

Become a Fellow of BMJ Case Reports today and you can:

- Submit as many cases as you like

- Enjoy fast sympathetic peer review and rapid publication of accepted articles

Access all the published articles

Re-use any of the published material for personal use and teaching without further permission

Customer Service

If you have any further queries about your subscription, please contact our customer services team on +44 (0) 2071111105 or via email at support@bmj.com.

Visit casereports.bmi.com for more articles like this and to become a Fellow 